\title{
The Relation between Major Depression and Plasma levels of Cytokines and High Sensitivity C-Reactive Protein
}

\author{
*Amr Zahra; * Eman Obaia; * Amira Hassouna; **Mohamed Ezat \\ Departments of Medical Biochemistry*and Psychiatry**, Faculty of \\ Medicine, Cairo University and Alfayoum University
}

\begin{abstract}
A little is known about the relation of plasma cytokines with psychological risk factors, such as hopelessness, and the severity of depressive symptoms. The present work studied the effect of depression on plasma interleukin (IL)-1 1, IL-6 and high sensitivity C-reactive protein (hsCRP) in 40 subjects. Participants included two groups; patient group included 20 nonsmoking males (aged 20-40 years), recruited from the psychiatry clinic at Kasr El-Ainy Hospital fulfilling the DSM-IV Axis I disorders criteria for major depression. Control group included 20 healthy, nonsmoking males (age matched with no current or past history of psychiatric disorders). After an overnight fast, blood samples were collected and plasma IL-6, IL$1 \beta$, and hsCRP were determined using enzymatic-linked immunosorbent assay (ELISA), also fasting total cholesterol (TC) and high density lipoprotein-cholesterol $(H D L-C)$ were estimated on the same day that the Beck Depression Inventory (BDI), Hopelessness Scale (HS) and full psychiatric sheet were accomplished. The results of the study showed a significant increase in depressed patients compared to normal controls as regards mean scores of BDI, HS, IL-1 $\beta$, IL-6 and hsCRP. There was, also, a significant increase in both patients with moderate and severe depression compared to patients with mild depression as regards mean scores of BDI, IL-1B, IL-6 and hsCRP. There was, also, a significant difference between patients with mild hopelessness and those with moderate and severe hopelessness as regards mean scores of $H S, I L-1 \beta, I L-6$ and hsCRP. Conclusion: Patients with major depression revealed high levels of $I L-1 \beta, I L-6$ and $h s C R P$. That finding makes such patients more vulnerable to cerebrovascular accidents, where elevation of plasma cytokines and inflammatory markers are considered as risk factors for myocardial infarction.

Key Words: severity of depressive symptoms, - plasma interleukin-1 $\beta$ and -6 , $\cdot$ high sensitivity C-reactive protein, $\bullet$ Beck Depression Inventory, •Hopelessness scale, -healthy men.
\end{abstract}

\section{INTRODUCTION}

Major depression is a disorder that involves abnormalities in the central monoaminergic neurotransmitter system, which gives rise to behavioral changes and alterations in neurohormonal pathways. It has been suggested that the behavioral deficits, central monoamine abnormalities, and hypothalamic-pituitary-adrenal (HPA) axis activation observed in major depression are associated with alterations in immune function ${ }^{[1,2]}$. 
Much of the work, linking depression with inflammation, has been prompted by the search for potential shared etiological mechanisms that might explain the striking co-morbidity between these medical illnesses and major depression $^{[3]}$.

Evidence for increased inflammation in patients with major depression who are otherwise medically healthy have been repeatedly observed to have activated inflammatory pathways, as manifested by increased proinflammatory cytokines, increased acute-phase proteins and increased expression of chemokines and adhesion molecules $^{[4,5]}$

Cytokines are large (17- to 51$\mathrm{kD})$ hydrophilic molecules that are unlikely cross the blood-brain barrier. Four major hypotheses have been proposed for the mechanisms by which peripherally released cytokines communicate with the brain: 1) active transport of cytokines across the blood-brain barrier; 2) access of cytokines to the brain in areas where the blood-brain barrier is weak; 3) conversion of cytokine signal into secondary signals; and 4) transmission of cytokine signals along sensory afferents onto the relevant brain regions ${ }^{[2,6]}$.

The "macrophage theory of depression" was proposed considering the potent brain effects of proinflammatory cytokines such as IL$1 \beta$ and the association between pathological states of immune alteration and depression, increased serum concentrations of positive acute-phase proteins (C-reactive protein, haptoglobin and $\alpha_{1}$ - antitrypsin) and increased secretion of cytokines, particularly IL-6, after in vitro induction by mitogens, particularly IL-1ß, IL-6, and interferon gamma $(\text { INF- } \gamma)^{[7,8]}$.

Interleukin-1 $\beta$ (IL-1 $\beta$ ) is released as part of the acute phase immune response and can directly stimulate the release of corticotrophin-releasing hormone and thus induce HPA axis hyperactivity. Major depression has been shown to be accompanied by both an acute phase immune response, including raised IL- $1 \beta$ production and HPA axis hyperactivity ${ }^{[9]}$.

C-reactive protein (CRP) was the first acute-phase protein to be described as an acute phase reactant that increases dramatically in response to tissue injury or infection. It is synthesized primarily in the liver predominantly under transcriptional control by the cytokine IL- 6 and other pro-inflammatory cytokines, although other sites of local CRP synthesis and possibly secretion have been suggested $^{[10,11]}$

The effects of cytokines on the nervous system and the endocrine system close the loop between the brain and the immune system, which indicates that neural-immune interactions are bidirectional. IL- $1 \beta$ and IL-6 exert potent enhancing effects on the HPA axis by stimulating hypothalamic corticotropin-releasing hormone $(\mathrm{CRH})^{[12,13,14]}$.

An immune reaction, as measured by proinflammatory cytokines, is positively correlated with depressive symptoms and with the impaired feedback regulation of the HPA axis in major depression. IL-6 stimulates the HPA axis and exerts its actions on immune cells ${ }^{[\underline{12}]}$. It has been reported 
that IL-1ß-induced adrenocorticotropic hormone, corticosterone, and IL- 6 production is mediated by IL-1 type I receptors ${ }^{[\mathbf{9}, 15]}$.

\section{Aim of the Work}

The current work aimed to study the possible relation between plasma IL-6, IL-1 $\beta$, and hsCRP with both severity of depressive symptoms and hopelessness.

\section{SUBJECTS \& METHODS}

The present study was conducted on 40 subjects. Participants included two groups; patient group included 20 healthy, nonsmoking males (aged 2040 years) recruited from the Psychiatry Clinic at Kasr El-Ainy Hospital fulfilling the DSM-IV Axis I disorders $^{[16]}$, criteria for major depression. Control group included 20 healthy, nonsmoking males (age matched with no current or past history of psychiatric disorders). Exclusion criteria included past history or current diagnosis of medical conditions that could alter plasma cytokines (e.g. asthma, allergies, arthritis, cancer or cardiovascular disease) or using antidepressant medications. Two weeks preceding collection of blood samples, the participants had no acute infections or injuries and they were advised not to receive any medications and over-thecounter (OTC) preparations, including daily low-dose aspirin. Informed consent was obtained before study participation.

Assessment of Plasma Interleukein1及, Interleukein-6, hsCRP and Lipids

After overnight fasting for 12 hours, blood samples were collected from antecubital vein by venipuncture between 9:00 AM and 10:00 AM. For plasma IL-1 $\beta$ and IL-6 and hsCRP, blood samples were collected in 7-ml pyrogen-free tubes with EDTA. Whole blood samples remained chilled for approximately 30 minutes. Blood samples were centrifuged at $3000 \mathrm{rpm}$ and plasma was separated and stored at $-20^{\circ} \mathrm{C}$ until time of assay.

Plasma IL-1 $\beta^{[22]}$ and IL-6 $6^{[23]}$ levels were measured by an enzymelinked immunosorbent assay (ELISA) kit, provided by BioSource Europe S.A., Belgium, using Mrx dynatech laboratories ELISA reader and concentrations were determined from a standard curve. The detectable limit for both plasma IL-1 $\beta$ and IL-6 was $<1 \mathrm{pg} / \mathrm{mL}$ and the intra- and interassay coefficients of variation were $<5 \%$ and $<10 \%$, respectively.

Plasma hsCRP ${ }^{[24]}$ levels were measured by an enzyme-linked immunosorbent assay (ELISA) diagnostic kit, provided by DiaMed EuroGen, Belgium using Mrx dynatech laboratories ELISA reader. Samples were diluted prior to assay. A starting dilution of 1:100 with Standard A/Sample Diluent (zero Standard) was done prior to assay. Results for these samples were multiplied by 100 to correct for the additional dilution.

Serum total cholesterol and HDL cholesterol [25] were measured enzymaticaly using kits provided by SENTINEL CH.

\section{Psychiatric Procedures}

After blood sampling, subjects completed the 21-item BDI $\underline{[17]}$ and Hopelessness Scale and full psychiatric sheet was obtained with 
special stress on past and family history $^{[18]}$.

Beck Depression Inventory (BDI)

The original BDI consists of 21 questions about the subject feeling in the last week. When the test is scored, a value of 1 to 5 is assigned for each answer. The standard cut-offs are as follows: 21-41 indicates that a person is not depressed, 42-62 indicates mildmoderate depression, 63-83 indicates moderate-severe depression and 84105 indicates severe depression ${ }^{[19,20]}$.

\section{Beck Hopelessness Scale (HS)}

The 20-item self-report instrument assesses the degree to which an individual holds negative expectations towards their future. The standard cut-offs are as follows: $0-8$ indicates that a person has no significant hopelessness, 8-12 indicates mild-moderate hopelessness, 12-16 indicates moderate-severe hopelessness and more than 16 indicates severe hopelessness with risk of suicide ${ }^{[21]}$.

\section{Statistical methods}

Continuous variables were expressed by mean and standard deviation and compared using Student unparred t-test for comparison of two groups or one-way ANOVA (analysis of variance) for more than 2 groups' comparison. They were correlated to each others using Pearson correlation

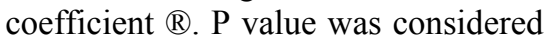
significant when less than 0.05 .

\section{RESULTS}

Table (1): Comparison between control group and patient group as regard mean scores of age, BMI, TC, HDL-C, BDI, HS, IL-1 $\beta$, IL-6 and hsCRP.

\begin{tabular}{|l|l|l|l|}
\hline & Control group & Patient group & \\
\hline & Mean \pm SD & Mean \pm SD & P value \\
\hline Age (yr) & $28.76 \pm 0.44$ & $27.98 \pm 0.52$ & $>0.05$ \\
\hline TC (mg/dL) & $22.69 \pm 0.26$ & $23.16 \pm 0.76$ & $>0.05$ \\
\hline HDL-C (mg/dL) & $172.13 \pm 5.74$ & $171.94 \pm 4.94$ & $>0.05$ \\
\hline BDI & $46.8 \pm 1.87$ & $50.2 \pm 2.25$ & $>0.05$ \\
\hline HS & $25.98 \pm 1.08$ & $80.12 \pm 9.46$ & $<0.001^{*}$ \\
\hline Plasma IL-1; (pg/mL) & $5.32 \pm 0.44$ & $18.32 \pm 3.67$ & $<0.001^{*}$ \\
\hline Plasma IL-6 (pg/mL) & $4.94 \pm 0.54$ & $25.47 \pm 4.67$ & $<0.001^{*}$ \\
\hline Plasma hsCRP (mg/L) & $5.46 \pm 0.54$ & $26.45 \pm 4.31$ & $<0.001^{*}$ \\
\hline
\end{tabular}

${ }^{*} p<0.05=$ significant

BMI: body mass index, TC: total cholesterol, HDL-C: high density lipoproteincholesterol, BDI: Beck Depression Inventory, HS: Hopelessness Scale, IL: interleukin, hsCRP: high sensitivity C-reactive protein. 
There was a significant increase in patients with major depression when compared to control group as regards BDI, HS, plasma IL-1 $\beta$, IL-6 and hsCRP. There was no significant difference between the patient group and control cases as regards age, BMI, total cholesterol and HDL cholesterol as shown in table (1).

Table (2): Plasma cytokines and hsCRP among different grades of depression and hopelessness in patient group

\begin{tabular}{|c|c|c|c|}
\hline & \multicolumn{3}{|c|}{ Beck Depression Inventory (BDI) and Hopelessness Scale (HS) } \\
\hline & Mild (n=6) & Moderate $(n=8)$ & Severe $(n=6)$ \\
\hline IL-1及 (pg/mL) & a $15.675 \pm 1.14$ & b $27.17 \pm 0.33$ & b $29.16 \pm 0.62$ \\
\hline IL-6 (pg/mL) & a $15.675 \pm 0.22$ & b $27.79 \pm 0.65$ & b $30.31 \pm 0.41$ \\
\hline hsCRP(mg/L) & a $7.30 \pm 0.45$ & b $13.059 \pm 0.58$ & b $13.83 \pm 0.57$ \\
\hline
\end{tabular}

*Different letters in each row mean significant difference.

IL: interleukin, hsCRP: high sensitivity C-reactive protein.

Concerning BDI and HS, there was a significant difference between patients scoring moderate and severe $\mathrm{BDI}$ and $\mathrm{HS}$ as regards mean scores of IL-1 $\beta$, IL-6 and hsCRP when compared to patients scoring mild
BDI. There was no significant difference between patients scoring moderate and those scoring severe $\mathrm{BDI}$ and $\mathrm{HS}$ as regards mean scores of IL-1 $\beta$, IL-6 and hsCRP as shown in table (2).

Table (3): Comparison between past history of depression and plasma cytokines in patient group

\begin{tabular}{|l|l|l|l|}
\hline & Positive (n=6) & Negative(n=14) & P-value \\
\hline Mean BDI & $93.16 \pm 1.76$ & $67.08 \pm 1.1$ & $<0.001^{*}$ \\
\hline IL-1及 (pg/mL) & $26.54 \pm 0.55$ & $24.4 \pm 1.06$ & $<0.001^{*}$ \\
\hline IL-6 (pg/mL) & $24.7 \pm 0.86$ & $22.2 \pm 1.03$ & $<0.001^{*}$ \\
\hline hsCRP (mg/L) & $13.15 \pm 0.34$ & $11.13 \pm 1.07$ & $<0.001^{*}$ \\
\hline
\end{tabular}

$* p<0.05=$ significant.

IL: interleukin, hsCRP: high sensitivity C-reactive protein.

As regards mean scores of BDI, IL-1 $\beta$, IL-6 and hsCRP, there was a significant difference between patients with positive past history of depression when compared to those with negative past history of depression as shown in table (3). 
Table (4): Correlation between age, BMI, total cholesterol, HDL-cholesterol, BDI, HS, IL-1 $\beta$, IL-6 and hsCRP in patient group

\begin{tabular}{|c|c|c|c|c|c|c|c|c|c|}
\hline & Age & BMI & $\mathrm{C}$ & HDL-C & BDI & HS & IL-1及 & IL-6 & hsCRP \\
\hline Age & ----- & $\begin{array}{l}\mathrm{r}=-.303 \\
\mathrm{P}=.193\end{array}$ & $\begin{array}{l}\mathrm{r}=-.023 \\
\mathrm{P}=.923\end{array}$ & $\begin{array}{l}\mathrm{r}=.039 \\
\mathrm{P}=.87\end{array}$ & $\begin{array}{l}\mathrm{r}=-.102 \\
\mathrm{P}=.669\end{array}$ & $\begin{array}{l}\mathrm{r}=.089 \\
\mathrm{P}=.708\end{array}$ & $\begin{array}{l}\mathrm{r}=.129 \\
\mathrm{P}=.588\end{array}$ & $\begin{array}{l}\mathrm{r}=.074 \\
\mathrm{P}=.756\end{array}$ & $\begin{array}{l}\mathrm{r}=.154 \\
\mathrm{P}=.516\end{array}$ \\
\hline BMI & & ------ & $\begin{array}{l}\mathrm{r}=.022 \\
\mathrm{P}=.927\end{array}$ & $\begin{array}{l}\mathrm{r}=-.05 \\
\mathrm{P}=.833\end{array}$ & $\begin{array}{l}\mathrm{r}=.320 \\
\mathrm{P}=.169\end{array}$ & $\begin{array}{l}\mathrm{r}=.014 \\
\mathrm{P}=.955\end{array}$ & $\begin{array}{l}\mathrm{r}=-.002 \\
\mathrm{P}=.993\end{array}$ & $\begin{array}{l}\mathrm{r}=-.027 \\
\mathrm{P}=.910\end{array}$ & $\begin{array}{l}\mathrm{r}=-.033 \\
\mathrm{P}=.889\end{array}$ \\
\hline $\mathrm{C}$ & & & ------ & $\begin{array}{l}\mathrm{r}=.027 \\
\mathrm{P}=.74\end{array}$ & $\begin{array}{l}\mathrm{r}=-.110 \\
\mathrm{P}=.645\end{array}$ & $\begin{array}{l}\mathrm{r}=-.183 \\
\mathrm{P}=.440\end{array}$ & $\begin{array}{l}\mathrm{r}=-.197 \\
\mathrm{P}=.406\end{array}$ & $\begin{array}{l}\mathrm{r}=-.203 \\
\mathrm{P}=.391\end{array}$ & $\begin{array}{l}\mathrm{r}=-.195 \\
\mathrm{P}=.410\end{array}$ \\
\hline HDL-C & & & & ------ & $\begin{array}{l}\mathrm{r}=-.144 \\
\mathrm{P}=.546\end{array}$ & $\begin{array}{l}\mathrm{r}=-.184 \\
\mathrm{P}=.439\end{array}$ & $\begin{array}{l}\mathrm{r}=-.218 \\
\mathrm{P}=.356\end{array}$ & $\begin{array}{l}\mathrm{r}=-.213 \\
\mathrm{P}=.367\end{array}$ & $\begin{array}{l}\mathrm{r}=-.182 \\
\mathrm{P}=.443\end{array}$ \\
\hline BDI & & & & & ------ & $\begin{array}{l}\mathrm{r}=.885^{*} \\
\mathrm{P}<.001^{*}\end{array}$ & $\begin{array}{l}\mathrm{r}=.827^{*} \\
\mathrm{P}<.001^{*}\end{array}$ & $\begin{array}{l}\mathrm{r}=.853^{*} \\
\mathrm{P}<.001\end{array}$ & $\begin{array}{l}\mathrm{r}=.804^{*} \\
\mathrm{P}<.001\end{array}$ \\
\hline HS & & & & & & ----- & $\begin{array}{l}\mathrm{r}=.983^{*} \\
\mathrm{P}<.001^{*}\end{array}$ & $\begin{array}{l}\mathrm{r}=.992 * \\
\mathrm{P}<.001 *\end{array}$ & $\begin{array}{l}\mathrm{r}=.957^{*} \\
\mathrm{P}<.001\end{array}$ \\
\hline 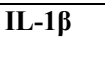 & & & & & & & ----- & $\begin{array}{l}\mathrm{r}=.986^{*} \\
\mathrm{P}<.001 *\end{array}$ & $\begin{array}{l}\mathrm{r}=.957^{*} \\
\mathrm{P}<.001^{*}\end{array}$ \\
\hline IL-6 & & & & & & & & ----- & $\begin{array}{l}\mathrm{r}=.963^{*} \\
\mathrm{P}<.001^{*}\end{array}$ \\
\hline hsCRP & & & & & & & & & ------ \\
\hline
\end{tabular}

As shown in table 4; there was positive significant correlations between scores of BDI when compared to scores of HS $\left(\mathrm{r}=.885^{*}\right.$, $\mathrm{P}<.001)$, IL-1 $\beta\left(\mathrm{r}=.827^{*}, \mathrm{P}<.001\right)$, IL$6 \quad\left(\mathrm{r}=.853^{*} \mathrm{P}<.001\right)$ and hsCRP $\left(\mathrm{r}=.804^{*}, \mathrm{P}<.001\right)$. There was, also, positive significant correlations between scores of HS when compared to scores of $\mathrm{BDI}\left(\mathrm{r}=.885^{*}, \mathrm{P}<.001\right)$, IL-1 $\beta \quad\left(\mathrm{r}=.983^{*}, \quad \mathrm{P}<.001\right), \quad$ IL-6 $(\mathrm{r}=.992 *, \quad \mathrm{P}<.001)$ and hsCRP $\left(\mathrm{r}=.957^{*}, \mathrm{P}<.001\right)$. There was, also, positive significant correlations between scores of IL-1 $\beta$ when compared to scores of BDI $\left(\mathrm{r}=.827^{*}\right.$, $\mathrm{P}<.001)$, HS $\left(\mathrm{r}=.983^{*}, \mathrm{P}<.001\right)$, IL-6 $\left(\mathrm{r}=.986^{*}, \quad \mathrm{P}<.001\right)$ and hsCRP $\left(\mathrm{r}=.957^{*}, \mathrm{P}<.001\right)$. There was, also, positive significant correlations between scores of IL-6 when compared to BDI $\left(\mathrm{r}=.853^{*} \mathrm{P}<.001\right)$, HS $(r=.992 *, P<.001)$, IL-1 $\beta\left(r=.986^{*}\right.$, $\mathrm{P}<.001)$ and hsCRP $\left(\mathrm{r}=.963^{*}\right.$,
$\mathrm{P}<.001)$. Finally, there was positive significant correlations between scores of hsCRP when compared to scores of BDI $\left(\mathrm{r}=.804^{*}, \mathrm{P}<.001\right)$, HS $\left(\mathrm{r}=.957^{*}, \mathrm{P}<.001\right), \quad$ IL-1 $\beta \quad\left(\mathrm{r}=.957^{*}\right.$, $\mathrm{P}<.001)$, and IL-6 $\left(\mathrm{r}=.963^{*}, \mathrm{P}<.001\right)$.

There were, also, no significant correlations between age, BMI, total cholesterol and HDL-cholesterol when compared to each other and to other biochemical parameters.

\section{DISCUSSION}

The current study examined the relation between plasma IL-6, IL-1 $\beta$, and hsCRP with both severity of depressive symptoms and hopelessness. Results indicated a significant effect of hopelessness and severity of depressive symptoms on plasma IL-6, IL-1 $\beta$, and hsCRP levels ${ }^{[26,27,28,29]}$ 
As regards mean scores of BDI, HS, plasma IL-6, IL-1 $\beta$, and hsCRP, the present study revealed a stastically significant increase in patients with major depression when compared to normal controls (table 1). These results (after exclusion of Age, BMI, and serum cholesterol as variables), might clarify the role of depression in altering levels of plasma cytokines and inflammatory markers.

The results of the present study were matched with those of Miller et al. ${ }^{[4]}$, who observed a $40 \%$ increase in C-reactive protein and a $36 \%$ increase in interleukin-6 levels in depressive adults. Furthermore, Andrei et al. ${ }^{[30]}$, observed similar results in elderly individuals. They, also, found a strong relation between depression and levels of C-reactive protein in both men and women; men with severe depression had $46 \%$ higher C-reactive protein levels. It has been suggested that depression promotes systemic inflammation and increases plasma levels of inflammatory cytokines like IL-6, IL-1 $\beta$, and acute-phase proteins like C-reactive protein ${ }^{[30,31]}$.

On the contrary, Steptoe, et al. ${ }^{[32]}$ found that, there were no association between BDI measures of depressive symptoms or hopelessness and markers of immune activation or inflammatory response. They concluded that measures of depressive symptoms, the choice of inflammatory and immune indices, and sample size, are unlikely to be responsible for these effects $^{[32]}$.

In the present study, patients with mild depression and hopelessness showed a significant lower levels when compared to those with moderate and severe depression and hopelessness as regards mean scores of BDI, HS, plasma IL- 6 , IL- $1 \beta$, and hsCRP. On the other hand, there was no significant difference between patients with moderate and those with severe depression as regards the same parameters. These results might underline the role of severity of depressive symptoms in altering levels of plasma cytokines and inflammatory markers (table2).

The findings of the present study were in concordance with those of Zorrilla, et al. ${ }^{[33]}$, who suggested that IL-6 is significantly associated with major depressive disorder (MDD), even though negative findings have also been reported by Reif, et al. ${ }^{[34]}$. Schiepers et al. ${ }^{[35]}$, stated that there is a paucity of evidence for the relation of severity of depressive symptoms to IL-6. On the other hand, KiecoltGlaser, et al. ${ }^{[36]}$, had suggested that severity of depressive symptoms and depressed mood are positively associated with IL-6 in healthy, older adults.

Pasic et al. ${ }^{[37]}$, concluded that, IL6 is an important mediator of the acute-phase response, and higher levels of acute-phase proteins have been reported in depression. Kulmatycki and Jamali ${ }^{[38]}$, found that hyperproduction of IL-6 and IL-1ß have been associated with the severity of depression that is, higher serum levels have been found in patients with melancholic depression ${ }^{[39]}$.

Nishida et al. (2002) ${ }^{[40]}$ and Berk and Malhi $(2003)^{[41]}$, stated that cytokines may play a role in the pathophysiology of mood disorders. Of relevance to mood disorders, these cytokines can, also, induce "sickness behavior", which includes symptoms 
of fatigue, anorexia, anhedonia (loss of interest in usual activities), decreased psychomotor activity, and disappearance of body care activities. Similarly, Wichers and Maes [42] found that; these signs and symptoms accompany the immunologic response to infection may overlap with the symptoms of major depression.

The present study revealed a significant difference between patients with positive past history of major depression when compared to those with negative past history of major depression (table 3) as regards mean scores of BDI, IL- 6 , IL- $1 \beta$, and hsCRP.

The results of Ballou, et al. ${ }^{[43]}$ and those of Ershler, et al. ${ }^{[44]}$ found that circulating levels of IL-6, CRP, and other biomarkers of inflammation in healthy volunteers increase with age, although in those studies the definition of healthy status was questionable $^{[45]}$. On the contrary, Ahluwalia et al. ${ }^{[46]}$, screened participants with strict criteria for good health, adequate nutrition, and absence of diseases failed to detect any significant difference in the production of IL- $1 \beta$ and IL- 6 between young, middle-aged, and older participants.

The present study revealed in the patient's group a positive significant correlation between mean scores of BDI when compared to HS, plasma IL-6, IL-1 $\beta$, and hsCRP. Also, a similar positive significant correlation was obtained between scores of HS when compared to plasma IL-6, IL$1 \beta$, and hsCRP. These findings might highlight the relation between depressive symptoms and hopelessness on one hand and the plasma cytokines and inflammatory markers levels on the other hand (table 4).

The findings of the present study were in concordance with those of Raison et al., ${ }^{[47]}$, who found a significant positive correlation between cytokine production and acute-phase proteins, which suggests that activation of the inflammatory response system in depression is associated with increased production of the proinflammatory cytokines IL$1 \beta$, IL-6, and INF- $\gamma$.

Schiepers et al. ${ }^{[35]}$, also, found that immune reaction as measured by proinflammatory cytokines is positively correlated with depressive symptoms and with the impaired feedback regulation of the HPA axis in major depression.

Stoney and Engerbretson ${ }^{[48]}$, stated that hyperproduction of IL-6 and IL- $1 \beta$ have been associated with the severity of depression; that is, higher serum levels have been found in patients with melancholic depression (similar to Kulmatycki and Jamali, ${ }^{[38]}$ ).

On the contrary, Anisman, et al. ${ }^{[12]}$, concluded that IL $-1 \beta$ was increased in patients with dysthymia and that cytokine alteration was associated with the chronicity of illness and the age at onset.

Results of the study of Ridker et al. ${ }^{[28]}$, indicated that increasing levels of plasma IL- 6 and IL- $1 \beta$ are associated with an increasing number of traditional risk factors (e.g., hypertension, hyperlipidemia and smoking) ${ }^{[28]}$. Plasma IL-6 predicts future risk of cardiovascular events, as well as mortality, leading to heightened risk for mortality and 
cardiac events in men who are both hopeless and exhibit depressive symptoms, even in the mild to moderate range ${ }^{[26]}$. Consistent with that speculation, one study has reported greater all-cause mortality among hopeless individuals with depressive symptoms ${ }^{[49]}$. With this one exception, no other study has examined the combined effect of hopelessness and severity of depressive symptoms on health outcomes or cardiovascular end points. The current observations, therefore, add relevance to the argument for examining the joint effect of hopelessness and severity of depression in predicting outcome measures in epidemiological studies of cardiovascular disease as well as laboratory studies of biological risk factors.

The current study did not address possible mechanisms that could explain these observations. However, inclusion criteria (e.g., healthy, free of any acute medical conditions, nonsmokers, no medications whether prescribed or over-the counter) and statistical controls (e.g., age, BMI, lipids) implemented in this study support the conclusion that higher plasma IL-6 IL-1 $\beta$, and hsCRP levels among hopeless men with mild to moderate symptoms of depression are not mediated by these factors. Thus, elevated IL-6 IL-1 $\beta$, and hsCRP levels in hopeless men with depressive symptoms may be due, in part, to other factors, possibly stress-related in nature ${ }^{[50,51]}$.

\section{Conclusion}

The current study demonstrates the effect of hopelessness and severity of depressive symptoms on plasma concentration of IL-6 IL-1 $\beta$, and hsCRP. This observation was independent of the effects of traditional risk factors of cardiovascular disease such as age, smoking, BMI, blood pressure, and lipids that are known to influence plasma IL-6 IL-1 $\beta$, and hsCRP. The current findings raise the possibility that, among hopeless men with depressive symptoms, plasma IL-6, IL-1 $\beta$, and hsCRP are either markers for future risk of cardiovascular diseases or are pathophysiological mechanisms leading to increased risk of atherosclerotic cardiovascular disease (ASCVD). Whatever the case may be, the current findings broaden the understanding of how hopelessness in conjunction with depressive symptoms may impact cardiovascular disease risk via elevations in plasma IL-6 IL-1 $\beta$, and hsCRP. It remains to be seen whether that observations can be replicated in women and whether this relationship can be moderated by prophylactic interventions that include lifestyle changes and/or anti-inflammatory therapies, both are known to reduce the risk of cardiovascular disease.

\section{REFERENCES}

1. Weisse CS, (1992): Depression and immunocompetence: a review of the literature. Psychol. Bull., 111: 475-89.

2. Connor TJ and Leonard BE, (1998): Depression, stress and immunological activation: the role of cytokines in depressive disorders. Life Sci., 62: 583-606. 
3. Evans, D.L. et al., (2005): Mood disorders in the medically ill: scientific review and recommendations. Biol. Psychiatry, 58: 175-189.

4. Miller, G.E. et al., (2002): Clinical depression and inflammatory risk markers for coronary heart disease. Am. J. Cardiol., 90: 1279-1283.

5. Bouhuys, A.L. et al., (2004): Potential psychosocial mechanisms linking depression to immune function in elderly subjects. Psychiatry Res., 127: 237-24

6. Kahl, K.G. et al., (2005): Bone mineral density, markers of bone turnover, and cytokines in young women with borderline personality disorder with and without comorbid major depressive disorder. Am. J. Psychiatry, 162: 168-174.

7. Smith RS, (1991): The macrophage theory of depression. Med. Hypotheses, 35: 298-306.

8. Dantzer R, (1997): Stress and immunity: what have we learned from psychoneuroimmunology? Acta. Physiol. Scand. Suppl., 640: 43-6.

9. Owen B. M., Eccleston D., Ferrier I. N. et al., (2001): Raised levels of plasma interleukin-1 $\beta$ in major and postviral depression. Acta. Psychiatr. Scand., 103: 226-228.

10. Ross R, (1999): Atherosclerosis: an inflammatory disease. N. Engl. J. Med., 340: 115-126.

11. Libby $P$. and Ridker PM, (1999): Novel inflammatory markers of coronary risk. Circulation, 100: 1148-1150.
12. Anisman H, Ravindran AV, Griffiths J, (1999): Endocrine and cytokine correlates major depression and dysthymia with typical or atypical features. Mol. Psychiatry, 4: 182-8.

13. Levine, J. et al., (1999): Cerebrospinal cytokine levels in patients with acute depression. Neuropsychobiology, 40: 171176.

14. Lanquillon, S. et al., (2000): Cytokine production and treatment response in major depressive disorder. Neuropsychopharmacology, 22: 370379.

15. Thomas, A.J. et al., (2005): Increase in interleukin-1beta in late-life depression. Am. J. Psychiatry, 162: 175-177.

16. Ventura, J., Liberman, R. P., Green, M. F., and A., et al., (1998): Training and quality assurance with the Structured Clinical Interview for DSM-IV (SCID-I $\backslash P)$. Psychiatry Research, 79:163-173.

17. Beck AT, Steer RA. and Garbin MG, (1988): Psychometric properties of the Beck Depression Inventory: 25 years of evaluation. Clinical Psych., Review; 8: 77100.

18. Nezu AM, Nezu CM, McClure KS, et al., (2002): Assessment of depression. In: Gotlib IH, Hammen CL, editors. Handbook of depression. New York: Guilford Press, p. 61-85.

19. Beck, A.T., (1972): “Depression: Causes and Treatment" Philadelphia: University of Pennsylvania Press, ISBN 08122-1032-8. 
20. Beck, A.T., Steer, R.A. and Brown, G.K., (1996): "Manual for the Beck Depression Inventory-II". San Antonio, TX: Psychological Corporation.

21. Beck AT, and Weissman A, (1974): The measurement of pessimism: the Hopelessness Scale. J. Consult. Clin. Psy., 47:861-863.

22. Dinarello C.A., (1984): Interleukin-1 and the pathogenesis of the acute phase response. N. Eng. J. Med., 311:1413-1418.

23. Sakamoto K. et al., (1994): Elevation of circulating IL-6 after surgery; factors influencing serum level. Cytokine, 6:181-186.

24. Ridker PM, (2003): High sensitivity C-reactive protein and cardiovascular risk: rationale for screening and primary prevention. Am. J. Cardiol., 92(4B): $17 \mathrm{k}-22 \mathrm{k}$.

25. Trinder, P., (1969): Enzymatic colorimetric method for determination of plasma glucose and serum cholesterol according to Trinder mod. Ann. Clin. Biochem., 4: 6-24.

26. Yudkin JS, Kumari M, Humphries SE, (2000): Inflammation, obesity, stress, and coronary heart disease: is interleukin-6 the link? Atherosclerosis, 148: 209-14.

27. McCarty MF, (1999): Interleukin-6 as a central mediator of cardiovascular risk associated with chronic inflammation, smoking, diabetes, and visceral obesity: downregulation with essential fatty acids, ethanol, and pentoxifylline. Med. Hypotheses, 52: 465-77.

28. Ridker PM, Rifai N, Stampfer MJ, (2000): Plasma concentration of interleukin- 6 and the risk of future myocardial infarction among apparently healthy men. Circulation, 101: 1767-72.

29. Chae CU, Lee RT, Rifai $N$, et al., (2001): Blood pressure and inflammation in apparently healthy men. Hypertension, 38: 399-403.

30. Andrei AM, Fraguas R, Telles RMS et al., (2007): Major Depressive Disorder and Inflammatory Markers in Elderly Patients with Heart Failure. Psychosomatics, 48:319-324.

31. Danner M, Kasl S, Abramson J et al., (2003): Association between depression and elevated C-Reactive Protein. Psychos. Med., 65: 347-356.

32. Steptoe, S. R. Kunz-Ebrecht, and Owen N., (2003): Lack of association between depressive symptoms and markers of immune and vascular inflammation in middle-aged men and women. Psychological Medicine, 33: 667-674 Cambridge University Press.

33. Zorrilla EP, Luborsky L, McKay JR, et al., (2001): The relationship of depression and stressors to immunological assays: a metaanalytic review. Brain Behav. Immun., 15: 199226.

34. Reif W, Pilger F, Ihle $D$, et al., (2001): Immunological differences between patients with major depression and 
somatization syndrome.

Psychiatry Res., 105: 165-74.

35. Schiepers OJG, Wichers MC and Maes M (2005): Cytokines and major depression. Progress in Neuro-Psychopharmacology and Biological Psychiatry, 29 (4): 637-638.

36. Kiecolt-Glaser JK, Preacher KJ, MacCallum RC et al., (2003): Chronic stress and agerelated increases in the proinflammatory cytokine IL-6. PNAS., 100 (15): 9090-9095.

37. Pasic J, Levy WC and Sullivan $M$ (2003): Cytokines in Depression and Heart Failure. Psychosomatic Medicine, 65:181193.

38. Kulmatycki KM. and Jamali F (2006): Drug Disease Interactions: Role of Inflammatory Mediators in Depression and Variability in Antidepressant Drug Response. J. Pharm. Pharmaceut. Sci., 9(3): 292-306.

39. Maes M., (1995): Evidence for an immune response in major depression: a review and hypothesis. Prog. Neuropsychopharmacol. Biol. Psychiatry, 19: 11-38.

40. Nishida A, Hisaoka $K$, Zensho H, et al., (2002): Antidepressant drugs and cytokines in mood disorders. Int. Immunopharmacol., 2(12):1619-26.

41. Berk, M and Malhi, GS (2003): Mood disorders: mechanisms and pathophysiology. Acta. Neuropsychiatrica, 15(6):307-308.

42. Wichers $M$ and Maes $M$ (2002): The psychoneuroimmuno-pathophysiology of cytokine-induced depression in humans. The International Journal of Neuropsychopharmacology, 5: 375-388.

43. Ballou SP, Lozanski FB, Hodder S, et al., (1996): Quantitative and qualitative alterations of acute-phase proteins in healthy elderly persons. Age Ageing, 25: 224-230.

44. Ershler WB, Sun WH, Binkley N, et al., (1993): Interleukin-6 and aging: blood levels and mononuclear cell production increase with advancing age and in vitro production is modifiable by dietary restriction. Lymphokine Cytokine Res., 12: 225-230.

45. Wei J, Xu H, Davies JL, et al., (1992): Increase of plasma IL-6 concentration with age in healthy subjects. Life Sci., 51: 19531956.

46. Ahluwalia N, Mastro AM, Ball R, et al., (2001): Cytokine production by stimulated mononuclear cells did not change with aging in apparently healthy, well-nourished women. Mech. Ageing Dev., 122: 1269-1279.

47. Raison CL, Capuron $L$ and Miller AH (2006): Cytokines sing the blues: inflammation and the pathogenesis of depression. Trends in Immunology, 27 (1):24-31.

48. Stoney CM and Engerbretson TO, (2000): Plasma homocysteine concentrations are positively associated with hostility and anger. Life Sci., 66: 2267-75.

49. Barefoot JC, Williams RB, Siegler IC, (1995): Depressive 
affect, hostility, and socioeconomic status (SES): interrelationships and joint effects on health. Psychosom. Med., 57: 66.

50. Steptoe A, Willemsen G, Owen N, (2001): Acute mental stress elicits delayed increases in circulating inflammatory cytokine levels. Clin. Sci., 101: 185-92.

51. Paik IH, Toh KY, Lee C, (2000): Psychological stress may induce increased humoral and decreased cellular immunity. Behav. Med., 26: 139-41. 


\section{العلاقة بين الإكتئاب الجسيم و مستويات الكينات الخلويه والبروتين التفاعلي ج} عالي الحساسيه فى بلازما الام التوبن

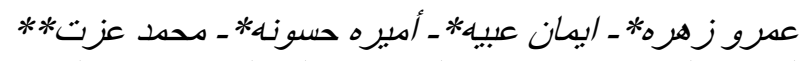

اقسام الكيمياء الحيويه الطبيه*ور الامر اض عبيه النفسيه**كليه الطب جامعه القاهره ورجامعه الفيوم

تهدف هذه الدراسة إلى إيجاد العلاقة بين الإكتئاب الجسيم ومستوى الكينات الخلويه

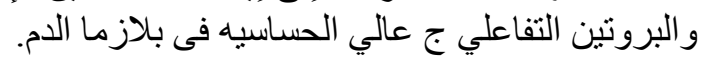

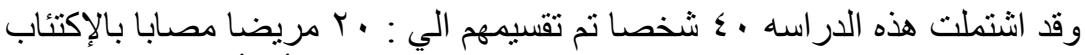

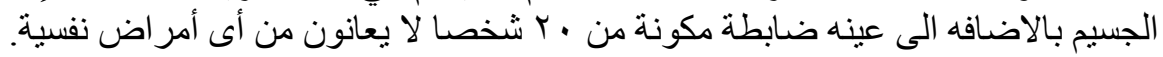

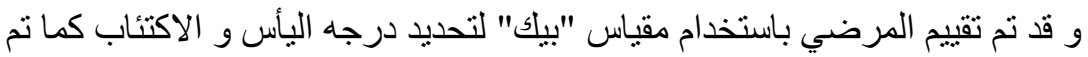

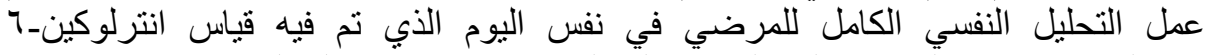
و انترلوكين- ابيتاو البروتين التفاعلي ج عالي الحساسيه فى بلازما الدي لهي لهم

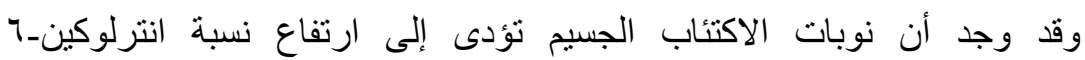

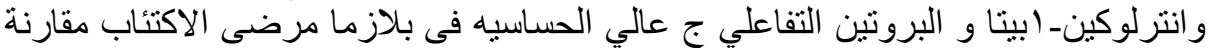
بالأشخاص الغير مصابين بالاكتئاب.

وتعد هذه المؤشرات من العلامات الخطرة حيث يكون مرضى الاكتئاب هم الاكثر عرضده للإصـابة بأمر اض القون القلب .

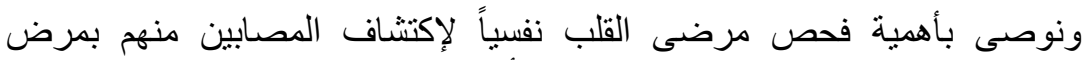
الإكتئاب ومساعدتهم على التغلب عليه سو اء بالعقاقير أو بجلسات العلاج النفسى لإنى 